\title{
Britain, UN and the Decolonisation of British Southern Cameroons: The Past Foundations of the Present day Ambazonia War of Independence in Cameroon
}

\section{Walter Gam Nkwi \\ ORCID iD: http://orcid.org/0000-0001-7205-0056}

\begin{abstract}
Content of abstract. This paper has two arguments: First it argues that the Ambazonian war was created partly by the process of decolonisation initiated by the erstwhile British territory in complicity with the United Nations. Secondly, the paper maintains that it was the failure of the post-colonial state elite to forge a sustainable and viable nation in Cameroon that led to the war. The two arguments are complementary - the failure of the post-independent state elite is as a consequence of the continuous manipulation of the former colonial powers. Archival files mined from the Buea National Archives and secondary sources from libraries in Cameroon and Europe were used as evidence for my argument. From these sources the paper concludes that the charter of the UN trusteeship which was given to Britain as a colonial power was never executed to the end. Thus, it was a dismal failure both to the United Nations and to Britain, and by extension, to the post-colonial government. The article hopes to contribute to the body of knowledge in the field of decolonisation. It provides some evidence of how Britain and France have played an enormous role in dividing people within the Cameroon nation-state that had future repercussions in how people are marginalised in the present. The article highlights a failure of Britain, the UN, and the post-colonial state, which have failed to initiate any peace-building after colonialism and decolonisation had torn the country apart.
\end{abstract}

Keywords: Ambazonia, British Cameroons, Decolonisation, United Nations. 


\section{Introduction: The Present in the Past}

Africa is at war with itself. Conflicts are rife in West, Central, and Southern Africa. A cursory survey of the hotspots of conflicts especially in West Africa points a finger to the way in which British territories were decolonised (Smith Jeppesen 2017:1-15). This does not exempt the French former colonies either. About thirty-one out of the 54 African states are grappling with secessionist and autonomous tendencies. It is a truism that of late, some Africanists scholars have attempted to research and explain the dynamics for Africa's remarkable 'secessionist deficit' to use the words of Nyamnjoh and Konings (2019). These scholars have identified the internal and external factors that have apparently accounted for the failure of success in the, past and to a large extent the ongoing secessionist movement in the continent of Africa (Forest 2004; Englebert Hummel 2005). Interestingly, these scholars although reviewing the secessionist movements critically, have overlooked the discussion on the Anglophone or Ambazonia war raging on in Cameroon. It is this gap that I wish to fill in this paper.

Modern Cameroon is made up of Anglophones and Francophones which reflects dual colonial legacy (Awasum 1998). Although it was initially colonised by Germany, most German cultural influences were obliterated by the French and British periods of administration (Nkwi 2013). The Anglophones in Cameroon are a minority, constituting about one-fifth of the population and occupying less than one tenth of the national territory (Awasum 1998). Recently, Anglophone Cameroonians have been seeking autonomy of an imaginary state which they called Ambazonia but which geographically constitutes the erstwhile British Southern Cameroons and which is today simply known as the Northwest and Southwest regions (Ngoh 2019). They started searching for an autonomous region within a federal framework as opposed to the unitary system of government that presently exists in the country, but when this failed, they resorted to outright independence. Scholarly debates, discussions, and speculations about the origin and the real motive for the Anglophone quest for autonomy are very topical and relevant for the Cameroon nation-building experiment. But there is either no unanimity on the issue between Anglophones and Francophones or the explanations afforded are simplistic and incomplete. By misinterpreting or misunderstanding wilfully the Anglophone desire for autonomy, Cameroonian authorities and their activities have further pushed the Anglophones to a tight corner in which they have 
decided to fight back since 2016. However, one of the causes which seems to be the convincing reason for what is going on in Anglophone Cameroon is the role which the United Nations and Britain played in her decolonising mission. The separatists movements, which is the name given to the Anglophones fighting for their autonomy, resorted to war with the Cameroon Francophone led government in 2017. The other cause is the failure of the post-colonial government of Cameroon to forge a sustainable and unified nation state.

The Anglophone War of Independence, also known as the Ambazonian War of Independence, began in January 2017 after the ring leaders of the Ambazonia struggle were kidnapped in Nigeria and brought back to Cameroon where they are jailed presently. The arrests were the final straw that escalated the simmering Anglophone marginalisation which is assumed by some Anglophones to have existed for more than 50 years. The Francophone dominated government failed to address the issues raised by the lawyers and teachers (Awasum 2020).

This paper has two objectives. Firstly, it is about the unfinished decolonisation process and the present war in Anglophone Cameroon. It was partitioned in 1916 after the First World War. Germany, the former colony was defeated by combined British and French forces. Cameroon was therefore partitioned between France and Britain with France taking 4/5 and Britain 1/5 (Elango 1985). The British section is what has come to be known today as Anglophone Cameroon. It became a League of Nations Mandated Territory and later United Nations Trust Territory between 1946 and 1961 ${ }^{1}$. This meant that within these periods there were two Cameroons. After independence in 1961, the French Cameroon in complicity with its former colonial power (France) sought, albeit in a subtle way, to re-colonise the former British Southern Cameroon, and for the past 57 years have almost subsumed and colonised a people who now assume that they have become second class citizens (Awasum 2020). Secondly, the post-colonial independent government, despite its attempts to forge a viable and sustainable state project, has

${ }^{1}$ See File Ba ( 1917)1, Cameroons League of Nations Annual Report, 1927; File Ab (72)1, Report by His Majesty's Government in the United Kingdom of Great Britain and Northern Ireland to the Trusteeship Council of the United Nations on the Administration of the Cameroons Under United Kingdom trusteeship for the Year 1947 (National Archives Buea, henceforth written as $\mathrm{NAB})$ 


\section{Walter Gam Nkwi}

contributed inadvertently to the outbreak of the Ambazonian War of Independence. Since January 2017, some Anglophone Cameroonians have been fighting to restore what they claim as their lost independence.

Using mostly archival and secondary sources, this paper questions the role of the United Nations in the era of decolonisation, and, by extension, the role of Britain as a League of Nation Mandated/UN Trusteeship power of Southern Cameroon. It argues that the Anglophone renaissance in Cameroon is a product of the very nature in which the United Nations decolonised their Trust Territories between 1945 and 1960. With the UN Visiting Missions visits to Cameroon ( $1949 ; 1952 ; 1955$; and 1958) it would have been expected that it would have done an excellent job to decolonise its territories ${ }^{2}$. Unfortunately, the UN terminated their trusteeship. The case of Cameroon presents the complexities and contradictions of decolonisation encapsulated in the Anglophone Cameroon. Most Anglophone Cameroonians have been able to challenge the strategies which were used by the UN to grant her independence. Since the 1990s Anglophone Cameroonians have felt that the UN and the dominating Francophone have paid deaf ears to their plea. The Anglophone grievances exploded into guerrilla warfare since 2017. Britain as well as the United Nations did not take into account the distinctive characteristics of the Southern Cameroonians during the period of decolonisation. They rather looked for excuses to deny them independence as a private territory because they were not economically independent. Fifty years or so of the Ambazonian War shows that the foundations of the state were not firmly laid - first by the British and the UN and secondly by the post-colonial state.

Cameroon was first a German colony (1884 - 1916). During the First World War the Germans were ousted. From 1916, Cameroon became 'two Cameroons' - the English and the French Cameroons - which were administered as separate entities, first under the League of Nations Mandate and then under the United Nations Trusteeship. This has been elaborately captured in the literature of Cameroon historiography (Ardener et. al. 1960; Ardener 1967: 285-337; Johnson 1970; Rubin 1971; Joseph 1978; Kofele-Kale

${ }^{2}$ Documents on these visiting missions can be found in the Buea National archives in Southwest Cameroon. They show petitions from political parties, the formations of political parties, the social and economic development of the territory as well as petitions from several unions that were formed in the territory criticizing the British colonial administration. 
1980; Fanso 1985: 23-43; Mbuagbaw et. al. 1987; Chiabi 1989: 170- 199; Njeuma 1989; Ebune 1992; Ngoh 1996 and 2001; Milne 1999; Mbile 2000; Awasom 2004: 86-116). During the interregnum years of 1914 to 1916, the French and British attempted a joint administration of the territory which collapsed quickly because of disagreements over authority and territorial control (Elango 1987 \& 1985; Fanso 1989). France and Britain resorted to the partition of the territory and to administering it under the mandate of the League of Nations from 1922 to 1945 and under the United Nations Trusteeship from 1946 to 1961. Strikingly, Britain administered her part as part of the Southern Provinces of Nigeria and later as part of the Eastern Region of Nigeria, while France administered her part with French Equatorial Africa.

After the Second World War, Africa experienced much change. Those colonies which had not already become independent demanded independence. On 1 January 1960, French Cameroon obtained independence from France. On 1 October 1961, British Cameroon gained independence, and reunification, through a plebiscite organised by the United Nations (UN). It will be relevant to state upfront that the twin events of the partition and reunification are at the basis of the Ambazonian war today.

The two territories, which had been under different colonial administrations, became the Federal Republic of Cameroon, which lasted from 1961 to 1972 (Fanso 1999; Kale 1967). In a hastily organised referendum in 1972 the federal structures were superseded, and in their place was born the United Republic of Cameroon (Fanso 1989; Chem Langhee 1995; Bayart 1993). Ahmadu Ahidjo, its first president, resigned in 1982, and power changed hands to his constitutional successor, Paul Biya. Two years into Biya's presidency, through a Presidential Decree, the name of Cameroon was unilaterally changed from the United Republic of Cameroon to the Republic of Cameroon, which was the same name that French-speaking Cameroon had given at its independence on 1 January 1960 before the reunification event in 1961.

As a signpost to this paper, I will start by focusing on the methodology which I used in gathering data in the writing of this paper. Secondly, I will position a theoretical framework which will stand as an analytical framework of the paper. The third part focuses on the re-conceptualised decolonisation in Africa, in order to better situate the context and type of decolonisation as used in this paper. The fourth part examines the UN in Cameroon and with a special focus on Article 76b. The fifth part focuses on the British Strategy to frustrate Southern Cameroon's search for autonomy. Sixthly, the paper will focus on 
the Fiscal Commissions and the Myth of Southern Cameroon's Question of Financial Viability. The seventh part looks at the political leaders such as John Ngu Foncha, Nerius Mbile and Emmanuel Lifafe Endeley at the UN August Session. Finally, the organisation of Plebiscite in Southern Cameroons and its ramifications over 55 years is discussed.

\section{Methodology of Data Collection}

I used three basic methods in gathering the data for this paper. The first method was entering the archives. The National Archives Buea (NAB) which is located in Buea in the Southwest region of Cameroon was quite relevant. The NAB was established in 1959 through the efforts of two British Anthropologists: Edwin and Shirley Ardener (Orosz 1996; Austen 1974). The archives building in Buea holds more than 20,000 files which are not stored in the best of conditions because of humidity and destructive rodents such as rats. However, in these archives I consulted 20 files mostly on United Nations Visiting Missions, League of Nations Reports, and files dealing with the political activities in British Southern Cameroons between 1945 and 1961. I also consulted secondary sources in libraries in Cameroon and Europe. The secondary sources included articles in peer reviewed journals, books, and book chapters. I further used the internet and sourced for more secondary sources.

\section{Theoretical Framework}

I drew theoretical inspiration from two authors namely Mahmood Mamdani and Franz Fanon. Mamdani ( 1996) arguably maintains that the post-colonial state is more or less a colonial state. Using this line of reasoning this addresses the failure of post-colonial Cameroon state elites to build a united state which gives every citizen a true sense of belonging. On the other hand, Franz Fanon, addresses the emergence of a new moral being, a new African humanism born out of the historical experience of colonialism. According to Fanon, 'the future of culture and the richness of a national culture are also based on the values that inspired the struggle for freedom' (Fanon 1961:109). As far as the political elite which was fighting for political emancipation was concerned, Fanon further maintains that, 'the more things change, the more they remain the same' (1961:110). Fanon's work exposes the complications and complexities of 
nation-building project after the attainment of political independence in Africa, including Cameroon.

\section{Towards understanding Decolonisation in Africa}

Decolonisation has been interpreted in several forms today in Africa. At one end it has been interpreted as a moment in which Africans are reassuring their identity and looking for epistemic concept that reflects the African realities. The period of decolonisation which reached fever pitch in the post Second World War period affected most of the colonised world of Asia and Africa (Janses \& Osterhamme 2017). It happened in various and multifaceted ways with some being decolonised peacefully such as Ghana, Nigeria, Ivory Coast, and Senegal,while others through protracted wars like Algeria, Kenya, Namibia, and Zimbabwe. Simply put, it was the period of undoing colonialism. According to Christopher (1999:234) it was a period which,

following World War II the number of independent states increased dramatically as the colonial empires were disbanded and individual administrative colonies were granted the status of separate sovereign states. Since 1945 a total of 96 new states has been created as a result of the process of decolonization.

The United Nations which was created to replace the defunct League of Nations was charged with the duty of decolonisation. Within the United Nations, Britain, France, and the United States of America were the most influential powers. However, the United States was not a colonial power and thus was not active in the decolonisation process. Britain and France remained the most active powers in that domain. Following the United Nations structure, and via Article 76b, colonial powers were entrusted with the duty to prepare:

to promote the political, economic, social, and educational advancement of the inhabitants of the trust territories, and their progressive development towards self-government or independence as may be appropriate to the particular circumstances of each territory and its peoples and the freely expressed wishes of the peoples concerned, and as may be provided by the terms of each trusteeship agreement (Gardinier 1963). 


\section{Walter Gam Nkwi}

To achieve this objective, the United Nations sponsored Visiting Missions, what was grandiosely called UN Visiting Missions to the colonies to collect petitions from the people on the ground and also to collect information on the political developments of the various territories.

Perhaps, because of the everhidden agenda of colonialism which is best known only to the colonial powers, much of this was done in good faith (Ngoh 2019). Consequently, decolonisation was in some places done in a rush as well and without the shared consent of the colonised. Above all, the colonial powers especially played at best a contested role which consequently have affected the different territories. However, to hold the UN visiting mission to ransom for the war going on in Anglophone Cameroon today is, to say the least, not being very objective. This is so because the post-colonial Cameroon government albeit attempts to resolve some of the grievances of the Anglophones which were exacerbated the war.

The dynamics which led the colonial powers to decolonise their territories in Africa are many and varied (Crowder 1984; Dudley 1984; Pearce 1982).The Second World War which erupted in Europe with Hitler's attack on Poland led the world once again into a war that had far reaching ramifications on the colony. Crowder ( 1982: 22) maintains rightly that:

The official enunciations concerning the future of the colonial empires in Africa in no way questioned the basis of the colonial relationship. Winston Churchill specifically stated that the clause in the Atlantic Charter, which he signed with President Roosevelt, affirming 'the right of all people to choose the form of government in which they live' and hoping 'to see sovereign rights and self-government restored to those who have been forcibly deprived of them' did not apply to the African colonies. He also made it quite clear that he had not become 'the king's First Minister in order to preside over the liquidation of the British Empire'. Similarly, the Free French stated categorically that the future of France's African territories was not to be 'self-government', but 'greater France'. Indeed, the assurance of the survival of their colonial empires in the post-war world formed a bond between Churchill and de Gaulle, who saw France's empire as the guarantee of her continuing status as world power. There was, however, a basic difference between the two colonial powers in that Britain did accept that decolonisation of her empire was inevitable, even if this would take place only in some 
very distant future as far as her African colonies were concerned. Britain also had written the walls of its Colonial Office .... a group of 'reformers' who were determined to bring that future nearer.

What comes out much clearer in the passage is the role of Britain and France. Their exchanges show in a way that they were reluctant to do away with their colonies. This calls to question the role of superpowers and above all the Atlantic Charter and the United Nations.

The joint statement, which was later dubbed the Atlantic Charter, outlined the aims of the United States and the United Kingdom for the postwar world. Amongst other things it included: no territorial aggrandisement, no territorial changes made against the wishes of the people, self determination, restoration of self-government to those deprived of it, reduction of trade restrictions, global cooperation to secure better economic and social conditions for all, freedom from fear and want, freedom of the seas, abandonment of the use of force, and disarmament of aggressor nations (Churchill 2010). The Atlantic Charter in a way paved the way for colonial powers to loosen their grips on the colonies. The adherents to the Atlantic Charter signed the United Nations Declaration on 1 January 1942, which was the basis for the modern United Nations.

Furthermore, the United Nations was created with a particular charter which was responsible for decolonisation. This was found in article $76 \mathrm{~b}$ of the UN Charter. according to which, the trusteeship power was entrusted to promote the political, economic, social, and educational advancement of the inhabitants of the trust territories, their progressive development towards selfgovernment or independence as may be appropriate to the particular circumstances of each territory and its peoples, the freely expressed wishes of the peoples concerned, and as may be provided by the terms of each trusteeship agreement (Ngoh 2001: 86).

\section{UN in Cameroon and Article 76b: An explanation}

Article 76(b) provided the legal ammunition which Cameroon nationalists were to use to gain a series of concessions from the colonial authority, Britain. Cameroonian nationalists began criticising the British government for governing British Southern Cameroon as part of the provinces of Eastern Nigeria. This was because the British had joined the British Cameroons to 


\section{Walter Gam Nkwi}

administer with Nigeria. In terms of language, the Southern Cameroons acquired the English language and evolved politically within the Eastern provinces of Nigeria. However, the Nigerian-Cameroon nexus was henceforth contested on grounds that it was a violation of the trusteeship status of Cameroon, and that the territory was entitled to an autonomous existence (Awasum 1998). First, following the formation of the League of Nations, Cameroon was placed under the League of Nations Mandate B. This meant that France and Britain who took over German Cameroon were to administer these territories directly under the league of Nations. The two powers never did so (Ngoh 2020). Instead, Britain claimed that because of pecuniary reasons British Southern Cameroon was administered as part of the Eastern Provinces of Nigeria. This meant that constitutional developments in Nigeria affected directly or indirectly the British Cameroon. This also allowed for the influx of Nigerians into Southern Cameroon in all spheres of life. The most domineering Nigerian indigenous group was the enterprising Igbos. (Amazee 1990:281293). To the British Southern Cameroon this was to have long deep consequences in the territory which is still reflected today.

The British colonial officers, especially the Governor-Generals in Nigeria, enacted constitutions that directly affected the British Southern Cameroons. Although these constitutions advanced the territory politically, the British and the UN in the end arm twisted the aspirations and dreams of the people of the territory. The British denied British Southern Cameroons independence as an autonomous state the reason being that it was weak economically (Ngoh 2020).

The British introduced various constitutions in Nigeria which directly affected British Southern Cameroons. The constitutions were the Richards, Macpherson, and Lyttelton's. In 1946 the British introduced the Richards Constitution which, in essence, partitioned Nigeria into the Northern, Western, and Eastern Regions, each endowed with a regional government. The British Southern Cameroon fell within the Eastern Region and was allocated two seats in the Eastern Regional House of Assembly at Enugu ${ }^{3}$. Two people from the region, Chief J. Manga Williams and Fon Vincent S. Galega II were nominated by the British Commissioner to represent the Southern Cameroons at the Regional House for a three-year renewal mandate (Ngoh 2001). This

${ }^{3}$ File Vc/b ( 1953) Kamerun National Congress (National Archives Buea henceforth cited as NAB). 
arrangement did not convince most Anglophone Cameroonians who were disgruntled and unhappy. This was fundamentally because the arrangement placed their territory under the Eastern Region of Nigeria. More crucially they felt it was a violation of their trusteeship status and consequently the UN arrangements. Therefore, the Richards constitution soon came under a virulent attack. Nigerian and Cameroonian nationalists acting under the canopy of the National Council for Nigeria and the Cameroons (NCNC) called for a total revision of the nebulous constitution ${ }^{4}$. Some of the Cameroonian politicians notably P.M. Kale, in the NCNC, complained about the lack of Southern Cameroonian representation in Lagos and the general backwardness of the Southern Cameroonian territory in terms of road infrastructure. He further emphasized the urgency of raising the territory to a region (Kale 1967). On the other hand, the Nigerians wanted the constitution to be improved upon, while Southern Cameroonians went further to ask for their territory to be granted an autonomous status (Awasum 1998). These demands and attacks led to the moribund of Richards Constitution.

The Richards Constitution was replaced by Sir Governor Macpherson who took over in 1948 and bowed to nationalist pressures to review the constitution. Interestingly the British appeared to have been very determined to canvass public opinion thoroughly on the type of government that the Africans desired ${ }^{5}$. Perhaps the British wanted to fulfill their dream of 'bringing civilization to the headen'. To achieve this, they put in place a select committee of the legislative Council which was therefore set up for that purpose and it recommended that public opinion should be consulted on the basis of questionnaires. A period of constitutional debates therefore were ushered into Nigeria and the Cameroons. Constitutional debates in the Southern Cameroons centered on the need to create a Southern Cameroons Region as the only way of focusing attention on the developmental needs of the territory. The Cameroons Youth League (CYL), an umbrella pressure group that comprised Cameroonian elites, campaigned for the reform of the Richards constitution in the direction of regional autonomy on the grounds of British neglect of the Southern Cameroons and Nigerian domination of the Cameroon people ${ }^{6}$. As

\footnotetext{
${ }^{4}$ Ibid.

${ }^{5}$ File Nc/B ( 1952) Constitutional changes in British Southern Cameroons.

${ }^{6} \mathrm{Va} / \mathrm{a}$, ( 1939), 2, Future Political Developments in Nigeria: Review of the Constitution, National Archives Buea, Cameroon.
} 
already mentioned, in the Southern Cameroons, the mass immigration of Igbos led them to occupy the administration, trade, and commerce which were dominated by Nigeria, a state of affairs which rendered the territory 'a colony of a colony' (Konings \& Nyamnjoh 1997). Consequently, there developed distrust and animosity towards Nigerians, especially towards the profiteering Igbo traders (Johnson 1970).

\section{British Strategy to Frustrate Southern Cameroon's Search for Autonomy}

The dream of a separate country/region expressed by Southern Cameroonian politicians did not work well with the British official policy. This led the Colonial Office initiate strategies to frustrate such an ambition. It put in place economic experts who were charged to carry out feasibility studies and conclude whether the territory was viable economically if it was left alone (Ngoh 2020). It was in this direction that Sir Louis Chick was invited to head a commission to study the territory and bring out conclusions. As far as the Chick Fiscal Commission Report of 1954 was concerned, the terms of reference of the Commission was to find if Southern Cameroons could be viable financially/economically to "pay its way without financial assistance from other parts of Nigeria, assuming that none of its revenues were henceforth shared with Northern Cameroons or with any other part of Nigeria' (Ngoh 2020:175). The report headed by Sir Louis Chick concluded that the territory 'would not ... be financially stable without external assistance' ${ }^{7}$. The report later on intimated that:

... a Southern Cameroon's Regional Government would not in the years immediately ahead be financially stable without external assistance. In good years it might pay its way with a slender margin, but in lean years it would have a deficit and it would have no reserves to fall back on if, over a period, the deficits exceed the surplus ${ }^{8}$.

7 Report of Fiscal Commissioner on Financial Effects of Proposed New Constitutional Arrangements (Lagos: Government Printers, 1953), 27.

${ }^{8}$ Ibid. 
The territory was rather given a 'quasi-regional' status with a Southern Cameroon House of Assembly. A 'quasi-regional' meant that, Southern Cameroon was granted a semi-autonomous territory with a government. This became known as the Buea government (Akiba 2021:110).

The new Governor was Oliver Lyttleton who was charged to oversee the territory. Secondly, elections were to be organised in the Territory and the outcome of the elections was also to be a determinant of whether a separate region was possible. Thus, Lyttleton promised the Southern Cameroon's leaders that His Majesty's Government would consider favourably the granting of a form of regional status to the Cameroons. At this time the first indigenous party, Kamerun National Congress (KNC) has been formed with a platform of a regional status for Southern Cameroons. Elections were held in the territory in 1953 and Emmanuel Endeley's party (KNC) won by a majority. The granting of a regional status would be a foregone conclusion if one was to go by the elections. Rather Lyttleton, favourably intimated that a fiscal commission would be set up to investigate the economic viability of the Southern Cameroons to determine its qualification for regional status ${ }^{9}$. The outcome of the October elections and the economic situation of the Southern Cameroons were to be used as the determinants for qualification for regional autonomy.

As already said, Endeley's KNC won a landslide victory in the 26 October 1953 elections by capturing 12 out of 13 seats in the Southern Cameroons with S.E. Ncha from Mamfe winning a lone seat as an independent candidate (Awasum 1998). The Kamerun Peoples Party (KPP) had no vote. The Southern Cameroonians by their votes had indicated their desire to separate from the Eastern Region. However, the fiscal commission that had been set up, headed by Sir Louis Chick to investigate the economic viability of the Southern Cameroons published its report which did not favour entirely the autonomist aspirations of the Cameroons. The report concluded that the Southern Cameroons would not be financially stable in the years ahead without external financial assistance ${ }^{10}$, which was another way of saying the territory could not be granted the same regional status as Nigeria's other regions.

Lyttleton interpreted the election results as an expression of the desire

${ }^{9}$ File Nc/B ( 1953)1, Record of Proceedings of Nigeria Constitution held in London in July and August 1953 (NAB).

${ }^{10}$ File Vc/6( 1954), Report of the Fiscal Commission on the Financial effects of the proposed New Constitutional Arrangements (HMSO London, 1954). 
of the Cameroons to secede from the Eastern Region. He bowed to the verdict of the polls by announcing that the Southern Cameroons would cease to be part of the Eastern Region (Awasum 2020). However, the Cameroons would remain part of the federation of Nigeria as a quasi-Federal territory owing to the state of the economy (Ezra 1967). He announced that Southern Cameroons would be granted a self-autonomous region. This was greeted by pomp and pageantry in the territory. Yet it was a drop of water in the desert because Southern Cameroons was still to remain within the federation of Nigeria.

\section{Fiscal Commissions and the Myth of Southern Cameroons Question of Financial Viability}

The financial economic viability of British Southern Cameroons in determining the territory's political future came to a forefront in 1954 with the findings of the Chick's Fiscal Report. Further, three financial economic reports on the financial/economic situation in the British Southern Cameroons were prepared. These were the Chick Fiscal Commission Report produced in 1954 (already discussed above), the Phillipson Report commissioned, in 1959 and the Kenneth Beril Report of 1960.

The Phillipson Report of 1959 also undertook a study of the economic viability of Southern Cameroons as an independent state. The report discouraged a customs barrier between an independent Southern Cameroons and Nigeria. It concluded by cautioning that revenues, mostly from agriculture in the Southern Cameroons, 'might just suffice to enable it to maintain and even modestly to expand its current services, but it would be a precarious handto-mouth existence' ${ }^{11}$. In fact, the report concluded that an independent Southern Cameroons at its 1959 stage of development was unwise because 'the available revenues would just suffice to enable it to maintain... a precarious hand-to-mouth existence, ${ }^{12}$. The last report was carried out by Kenneth Berril in 1960. He had been commissioned in December 1959. Unlike the Chick and Phillipson's Report, Berril was charged to carry out a survey of the territory. In 1960, the report was submitted with conclusions that were not so different

11 File Qb/a/ 1960/2(Top Secret), 'Report on the Economic Aspects of a Possible Reunification of the British Cameroons with the Republic of Cameroon by Kjell Anderson' (NAB).

12 Ibid. 
from the former reports carried out in the territory. In the opinion of the Berril report, the economic requirement of Southern Cameroons w an improved road system. In a letter to J.O. Field, the Commissioner of Cameroon, Kenneth Berril indicated that 'the most important form of communication in the territory is the road. Every commentator in the territory stressed the importance of roads as the key to the future' ${ }^{13}$.

The conclusions of Chick, Anderson, Beril and Phillipson were not coincidental assumptions especially to the British official circles. The British had all along wanted British Southern Cameroon to remain part of the Federal Republic of Nigeria and thus the feasibility studies were just a smokescreen to conclude their long-cherished dream. In 1946, Sir Lennox Boyd had clearly made up the official mind of Britain. Amongst other things he said that the Golden Key of the Bank of England would not be given to British Cameroon if she decided to join the Cameroon Republic and continued by saying that 'many of the best friends of the Cameroons do not foresee a destiny more likely to promote her happiness and prosperity than continued association with Nigeria' ${ }^{14}$.

That notwithstanding, and using data reported in the UK's 1954 Annual Report on the Trust Territory of British Cameroons to the UN, it gives a completely different picture from all the conclusions arrived at by the Fiscal Commissioners. Taking into consideration exports, the size of the tax-paying population, and other factors, Southern Cameroons contributed to roughly 84\% of the Trust Territories' GDP, from 1944 to 1961 (Ngoh 2001). Adjusting for Southern Cameroon's overwhelming contributions to British Cameroon's economy, projecting out to 1961, and accounting for weatherrelated setbacks in agricultural production, Southern Cameroons would have been profitable by over $£ 1$ million by 1959 (Ngoh 1999). The secret to Southern Cameroons' profitability lay in the massive agricultural complex, Cameroons Development Corporation (CDC), that was forcefully bequeathed to the British by the Germans in 1916 (Ngoh 2020 \& Konings 1993). This corporation produced hundreds of thousands of tonnes of bananas, rubber, cocoa, peppers,

13 File Qc ( 1960) Kenneth E. Beril to J.O. Fields, The Economy of the Southern Cameroons: A Report Submitted to J.O. Fields Commissioner of Southern Cameroons 25/August 1960 (NAB).

${ }^{14} \mathrm{Bb} / \mathrm{a} / 1960 / 1$, "Sir Lennox-Boyd and the economy of the future of Southern Cameroons Under UK Trusteeship, 1960” (NAB). 


\section{Walter Gam Nkwi}

palm oil, and kernels ${ }^{15}$. It employed over 42,000 people in 1954 in Southern Cameroons alone ${ }^{16}$. Economically, therefore the British Southern Cameroons was viable and vibrant economically to gain independence as an autonomous region. The economic conclusions of the commissioners on the future of the territory was further compounded by the United Nations despite the plea of Southern Cameroonian politicians for an autonomous region of the territory. The principal parties in the territory in 1959 were the Kamerun National Democratic Party (KNDP) led by John Ngu Foncha; the Cameroon National Congress (CNC) led by Emmanuel Lifafe Endeley, and the Kamerun Peoples Party (KPP) led by Nerius Namaso Mbile. These three political figures attended the UN session in August 1959.

\section{Foncha, Mbile and Endeley at the UN august Session}

This section examines the Southern Cameroonian politicians at the UN Assembly and their positions in relation to the independence of British Southern Cameroons; the British and the UN position in relation to the final solution to the problem of British Cameroons. Foncha, Mbile and Endeley who were representing the various political aspirations of the people of British Southern Cameroons found themselves at the UN assembly to explain the options they had chosen. For Foncha, what follows is unquestionably a statement that cannot be improved upon given the importance, the venue, and the circumstance under which it was pronounced. With France about to grant independence to French Cameroon in January 1960 and Nigeria assuring Southern Cameroons the full status of a region within their federation if it opted for integration, Endeley was accorded high political standing with the most attractive political proposition. Foncha now became a political rival to Endeley and so had to prove himself at the Assembly. Thus, Foncha fought back fiercely when he stated before the august body: 'I wish to say that I am mandated by the house of Assembly and the majority of the people of Southern Cameroons

${ }^{15} \mathrm{Ba} / \mathrm{c} / 1960 / 2$, Annual Report of the Cameroon Development Corporation for a number of years, 1951, 1952, 1955, 1956, 1957, 1958 and 1959 (NAB).

${ }^{16}$ Report by His Majesty's Government in the United Kingdom of Great Britain and Northern Ireland to the General Assembly of the United Nations on the Administration of the Cameroons under United Kingdom Trusteeship for the Year 1950 (London: HSMO, 1960). 
to place the following before the UN General Assembly as what they want' (Johnson 1970: 484).

A) That we want the separation of Southern Cameroons from the federation of Nigeria before the latter attains independence in 1960.

B) That Southern Cameroons be constituted into a separate entity and continue for a short time under the United Kingdom trusteeship. The trusteeship agreement should be modified to allow the Southern Cameroons to be administered separately from Nigeria. During this interim period, the Southern Cameroons will work towards complete independence.

C) That during the period of continued trusteeship the Southern Cameroons government will explore the possibility of a suitable unification with an independent French Cameroon and that the form of the union should be a federation ${ }^{17}$.

In 1958, while in London for Constitutional talks, the only Leader of the Opposition, Foncha and Augustine Ngom Jua (Vice President of the KNDP) lobbied seriously for an independent Southern Cameroons and financial assistance from the British government, but the British stuck to the Phillipson Report, which stated that the Southern Cameroons economy was dependent on bananas only, the only and main source of revenue for British Southern Cameroons and that it took only one serious storm to wipe out the whole crop.

However, it is relevant to note that this was one reason the Kamerun National Democratic Party (KNDP) disagreed with the Union Populations Camerounaise (UPC). Formed in 1948, the UPC stood for a very fast radical political future of Cameroons. Her platform was complete independence and reunification with the British Southern Cameroons. The party was banned in French Cameroon in 1955 and it sought refuge in British Southern Cameroons as One Kamerun (OK) party (Joseph 1978). Although sharing a common dream, the KNDP rather preferred a moderate stand. The KNDP emphasised independence before reunification so that the differences in economic development could be bridged. Thus, East and West Cameroons should have been reuniting as equals. Referring to the painful issue of independence for Southern

${ }^{17}$ File Vc/b ( 1958)1, Constitutional developments in the Trust territory of British Southern Cameroons. 


\section{Walter Gam Nkwi}

Cameroons, and that he (Foncha) had been cheated out of this option by a combination of impenetrable forces, he tersely revisited it during his last message as Prime Minister of West Cameroon. In a manner consonant with what weight this had placed on his mind in that last address, he said: 'Although our first step was independence before unification, independence nevertheless was denied to us. This was a clever move against unification itself. At the UN, the British put up a strong fight against independence for Southern Cameroons and maneuvered the UN to accept their proposal' (Ndi 1999: 105).

By any stretch of the imagination Britain appears not to have done a good job on Southern Cameroons compared to the French in French Cameroon, although the former was a lesser evil. Perhaps, time was not on the side of Britain to take longer and to prepare British Southern Cameroon for independence. Besides, the Cameroonians were cognisant of the wide economic disparities existing between the two Trust Territories for the reason that Britain had failed woefully in its trusteeship assignment. Article 76b of the Charter of the UN had obliged the administering authority to promote the political, economic, and social advancement of the inhabitants of the trust territories. Their progressive development towards self-government or independence as may be appropriate to the particular circumstances of each territory and its peoples and the freely expressed wishes of the people concerned may be provided by the terms of each trusteeship agreement. ${ }^{18}$

At the UN general assembly, it was clear to the officials that Britain had not done a good job in British Southern Cameroon. Britain needed to clear its image. She sent an official from the Colonial Office in Britain to access a reality that Cameroonians were living in the circumstances evident of British failure in executing their trusteeship commitment to the UN Treaty Council in Southern Cameroons. At the United Nations Trusteeship Committee (UNTC) examination of the official documents submitted by Britain, the Soviet Union delegate painted graphically the derelict state of the economy and the extremely low level of development in the territory after forty years of British rule. The performance of the British in Southern Cameroons was so dismal that he noted with enormous disappointment:

Industry in Cameroons was non-existent and agriculture still very

18 UN Doc T/8 Trusteeship Agreement of the Cameroons under French Administration. 
backward. There were no railways and the inadequacy of road network made certain areas inaccessible during the rainy season. The situation in the educational and medical fields ... was far from being satisfactory. The indigenous inhabitants had obviously come to the conclusion that they must take matters into their own hands recognising that independence provided the constitutions in which former ... trust territories would develop their full potentialities ${ }^{19}$.

Yet, the British colonial officials were not yet convinced that British Southern Cameroon should gain independence as a separate region. To make the point more emphatic clear, Sir Andrew Cohen wrote to the Secretary of State at the Foreign Office on 11 October 1960 on the British position with regard to the independence of Southern Cameroons. Amongst other things, Cohen said: 'Our policy remains strongly against a separate Southern Cameroons State...if Cameroons political parties combine to take action to establish an independent state, this would place us in an embarrassing position. With support of moderate Afro-Asians and others we have always argued that separate independence would produce an entirely unviable state. ${ }^{20}$

The double dealing by the British officials was persistent (Ndi 1999). Taking the cue a month later, Lord Perth, the British Minister of State at the Colonial Office, Sir John Marten of the same office did not hide his spite not just for Foncha but for the entire Southern Cameroons, especially when it came to comparing it with Northern Cameroon (Awasum 2020:268) Without any qualms of conscience, he declared bluntly:

What would worry me is if a sequel to the Southern Cameroons try for independence was that the Northern Cameroons went the same way. That would really, I think upset our relationship with Nigeria as a whole for which we must, at all costs, avoid. The Southern Cameroons and its inhabitants are undoubtedly expandable in relation to this ${ }^{21}$.

${ }^{19}$ Report by Her Majesty's Government in UK to the General Assembly of the UN for 1959 (London: HOSM, 1960),104; Also see Anthony Ndi, Africa and Second World War (Limbe, Cameroon: Presbook, 1999)

${ }^{20}$ Top Confidential, Secret Brief of 11 October 1960.

${ }^{21}$ Confidential Letter from Lord Perth to Sir John Marten of the Colonial Office, 12 October 1960 


\section{Walter Gam Nkwi}

This version conveyed much more than just spite and surprise and therefore it is a reason there should have been such inordinate dislike for Southern Cameroons as a separate state and its leadership. This eventually translated into Britain simply abandoning Southern Cameroons and its inhabitants into the hands of France and the Republic of Cameroon to please Nigeria. By hindsight, French Cameroon was guided carefully by France and Ahmadu Ahidjo eventually canvassed for the independence of French Cameroon which was gained in January 1960. With that independence, French Cameroon attained its sovereignty and took its seat at the United Nations. It had a flag, a motto, and a constitution (Ngoh 2020). On the other hand British Southern Cameroons was still lingering under the UN trusteeship control. By any stretch of imagination in case of bargaining, French Cameroon was to enter into a union from a stronger position. The UN had one last chance for the trust territory of British Cameroons - the plebiscite in which the attention of this paper now turns.

\section{The Last whip of the UN: Plebiscite in Southern Cameroon and impact 55 Years after}

It was clear that Southern Cameroons wanted independence first before negotiating integration with either French Cameroon or Nigeria and that the UN trusteeship should be extended for a few years to give some time for this to happen. Yet the British and UN went ahead and coined the questions to be decided by the electorate through a plebiscite. The two questions were:

a) Do you wish to achieve independence by joining the independence of the Federation of Nigeria?

OR

b) Do you wish to achieve independence by joining the independent Republic of Cameroon?

Britain and the UN therefore seemed to have left Southern Cameroons carefully without taking into consideration the citizens and their respective voices. The result of this was the outcome of the plebiscite which went in favour of British Cameroons voting to join the French Cameroon Republic (Percival 2008). The final result of all these was the reunification which appears today as one of the cornerstones of the present day Ambazonian War. 
Perhaps it is not an exaggeration to say that without reunification there might not have been any war in Cameroon. This is just speculation and not a subject of history. Today many former British Cameroonians claimed that the plebiscite turned out to be a mismatch and a marriage of inconvenience as the two states seemingly found it challenging in forging a nation-state sustainable enough to accommodate the two colonial cultures. Yet, a closer look shows that British Southern Cameroons, although voting for reunification with French Cameroon, could never have been on equal footing. The inequality from the beginning was obvious and consequently, in terms of...? policy, French Cameroon was to take the lead. As a result, after 55 years in a union with French Cameroon, some of the Anglophones have felt marginalised on all levels of society. Thus, from the beginning of 2017, some Anglophones both in Cameroon and diaspora started clamouring for an independent state which they call Ambazonia. Their assumed grievances are many and varied and need to be explored and appreciated.

On 21 November 2016, the Anglophone lawyers and teachers called for an indefinite, strike asking the government of Cameroon to maintain the bijural nature of the legal system, as well as the British-inspired subsystem of education which was being assimilated and sub-colonised by the French system of education and culture. By 'sub-colonise' we mean that France had colonized French Cameroon and French Cameroon is attempting to establish a further subordinate colony in Anglophone Cameroon. The strike paralysed the education sector, and Common Law lawyers were brutalised by the military for attempting a peaceful march to express their grievances after memos to the government was unacknowledged intentionally by the government. This strike in 2016 was the result of longstanding and ongoing marginalisation and the attempted assimilation and sub-colonization of the Anglophones and their identity in Cameroon (Awasum 2020).

On 22 September 2017, Anglophones of all walks of life came out in numbers with olive branches and a 'strange flag' that they hoisted in many administrative headquarters in the Northwest and Southwest regions of Cameroon. One week later (1 October 2017), defying military presence, they came out again and declared the restoration and independence of the state of Ambazonia. These twin events of 2017 related back to the 1916 partition after the defeat of Germany in World War One. The English-speaking population of Cameroon, at home and in the diaspora, had come out to demonstrate in numbers the need to restore what they view as 'the independence of Southern 


\section{Walter Gam Nkwi}

Cameroons,' in an area they call Ambazonia - the Northwest and Southwest regions, which are known as the Anglophone part of Cameroon. This name had existed long before the coming of the Germans and the partition of Cameroon in 1916 (Ardener 1967). These demonstrations have met with suppression from military forces, resulting in violence, the looting of villages, and the maiming and killing of many citizens. Thousands of people were displaced and thousands more had fled to Nigeria as refugees and were living in dire conditions in 2017 (Awasom 2020). The government reaction of brute force, instead of silencing Anglophones, had rather led to their radicalisation and the emergence of different groups, such as Ambazonia Defense Forces (ADF), Forces for the Total Liberation and Restoration of Ambazonia (TLRA), and Dragons of Lebialem (DL), to name but a few (Awasom 2020). The reaction of the government falls in line with Mamdani (1996) who maintains that the post-colonial state is not different from the colonial state. The Cameroon colonial state was brutal and frowned on any reaction from the citizens. The UPC war which ran from 1955 to 1970 was met with brute force (Joseph 1978)

As I stated earlier, the Anglophone minority constitutes 20 percent of the total population of Cameroon; the Anglophone Regions constitutes onefifth of the total land surface of the country. As a matter of fact, the Anglophone area of Cameroon consists of two of the country's 10 regions, the Northwest and the Southwest. It covers 16,364 sq. km of the country's total area of 475,442 sq. $\mathrm{km}$ and has about 8.5 million of Cameroon's 24 million inhabitants (2010 estimate) (Awasom 2020:143). The Anglophone minority has cried foul at their marginalisation, assimilation and sub-colonisation by the Francophoneled government. As far as marginalisation is concerned, some Anglophones feel that there has been too much monopolisation of power by the Francophone elite, with the crumbs going to some gluttonous and self-seeking Anglophone elites (Awasom 2020). They complain that certain positions and ministries in the country have been monopolized by the Francophones, so that Anglophones are always playing inferior positions. Even the recent appointment of two Anglophones as Ministers of Territorial Administration and Secondary Education has been considered as mere window dressing intended to appease Anglophones. Ethno-regional favouritism has intensified from the 1990s onwards. For instance, Takougang and Krieger ( 1998:94f) stated in August 1991 that of the 47 senior district officers, 37 were Beti (the main ethnic group from where the President comes, from the Francophone Cameroon side) as were three quarters of military generals, directors, and general managers of 
parastatals or state-owned enterprises, and 22 of the 38 high ranking bureaucrats who had been appointed in the newly created office of the Prime Minister were 'Beti'. According to them assimilation had occurred over the years as the French ways of life in terms of the language has gradually entered Anglophone Cameroon. Yet they have not refused consuming French bread nor drinking beer exclusively brewed in French Cameroon.

Most Anglophone Cameroonians claim the right to exist as citizens of Cameroon and to be treated as equals with other Cameroonians. They decry marginalization and treatment as second-class citizens. In as much as the conflict is touted as having to do with intergroup relations, the Francophone political elite have been at the center of Anglophone grievances. However, the conflict can only be understood fully within the politics of the post-colonial Cameroon state. The grievances take on their full meaning within the historical context of the political, social and economic periods spanning 1961- 1982, under Ahmadu Ahidjo's regime (1960 - 1982) and, under Paul Biya's regime since 1982.

Politically, there is general consensus that the roots of Anglophone conflict can be traced back to the partitioning of the former German Kamerun Protectorate after the First World War into British and French Mandates ( 1922- 1945) and a UN Trust territory ( 1945 - 1961). The partition sowed the seeds of the subsequent development of territorial differences in language and cultural legacies, which laid a very strong foundation for the construction of Anglophone and Francophone identities to the present. Even more relevant to understanding the Anglophone conflict is the type of state that the Francophone political elite imposed on the Anglophone minority during the constitutional deliberations which gave birth to the reunified state in 1961 (Njung 2019). The anglophones further maintain that during the constitutional negotiations, Foncha who led the Anglophone delegation proposed to Ahmadu Ahidjo who was the leader of the Francophone delegation a 'loose ' federation which would have protected both 'identities' in a union as a means to preserve the cultural heritage and identity of each. Contrary to Anglophone expectations, the political elite of the Francophone territory, which was already independent as of 1 January 1960, opted for a highly centralised form of federation, which, moreover, they considered as a transition to a unitary state.

Some Anglophones assume that, the nation-state project after reunifycation was the most decisive stage in their marginalization and near 'colonization'. For many Anglophones, nation-building was and is continuously 


\section{Walter Gam Nkwi}

driven by the firm and resolute determination of the Francophone political elite to dominate the Anglophone minority in the post-colonial state and to erase the cultural and institutional foundation of Anglophone identity through unitarism (Awasum 2020; Bayart 1978). This has gradually created an Anglophone consciousness which is the feeling of being recolonised and marginalized in all spheres of public life, thus becoming second-class citizens in their own country (Nyamnjoh \& Konings 2004: 192; Nyamnjoh \& Konings 2000; Eyoh 1986: 262).

Nowhere are the frustrations of the Anglophones e been so blatant than with Biya's unilateral change of the name of the country from the United Republic of Cameroon to the Republic of Cameroon in February 1984 through a Presidential Decree. In the change of the name many Anglophones protested because they saw in the name an independent Francophone Cameroon which existed before reunification in October 1961. The new name therefore appeared to deny that the Cameroonian state was composed of two distinct entities, namely the English and French speaking entities. Biya argued, unconvincingly, that the change of name reflected the maturity of the Cameroonian people who for close to 25 years of independence and reunification had finally overcome divisions caused by 70 years of European colonization (Biya 1987: 6).

Within Anglophone circles, this was the boldest step taken towards their assimilation by the Biya regime (Nyamnjoh \& Konings 2004). For them the new name was clear evidence that as far as Biya was concerned, the Anglophone territory and people had lost their identity and become an indistinguishable part of the former Republic of Cameroon. Other Anglophones argued that by this action, La République du Cameroun, the name of French-speaking Cameroon before reunification, had unilaterally seceded from the union and thus lacks a constitutional basis and legitimacy to continue claiming control of the former British Southern Cameroons. Those who defend this school of thought have often been inclined to appeal to the United Nations for assistance to its former Trust Territory in separating peacefully from Francophone Cameroon. This view was first expressed by the eminent Anglophone lawyer and first president of the Cameroon Bar Association, Fon Gorji Dinka. On 20 March 1985, Dinka addressed a memorandum to President Paul Biya titled The New Social Order. In that memorandum, he declared the Biya government to be unconstitutional and called for the Southern Cameroons to become independent and to be re- 
baptised as the Republic of Ambazonia (Nyamnjoh \& Konings 2004).

In the economic domain, Anglophones argue that their natural resources have over time and space been exploited by the Francophone-led government. They complain that their region has failed to benefit substantially from its rich oil resources, derived from the only oil refinery in the country, Société National de Raffinage (SONARA), located in Anglophone Cameroon but predominantly staffed by Francophones (Nyamnjoh \& Konings 2004). Furthermore, the Anglophones complain that the Francophones were responsible for the destruction of economic institutions in their region. For instance, the National Produce Marketing Board (NPMB), where West Cameroonian farmers saved their money, was destroyed in 1972 when it went under the control of the unitary government. In 1972, the reserves in the NPMB amounted to 72 billion FCFA which suggested that the institution was healthy economically (Ndongko 1975). Huge amounts of money were quickly embezzled (Ngoh 2020). In later years, the NPMB was liquidated due to mismanagement (Ndongko 1975).

Socio-culturally, Anglophones complain of continuous attempts at 'frenchification' or what Kofele-Kale ( 1987) describes as 'the Gallicising of public life,' which refers to the pre-eminence of French as the special language and of inherited French institutions and bureaucratic practices in all aspects of state administration and public life, not least in the Anglophone territory (Nyamnjoh \& Konings 2004: 193). Although, by constitution, the country is bicultural and bijural in nature, the common law and English sub-system of education has eroded gradually over the years. As early as 1967 there were already attempts to harmonise the elementary school system reducing the seven school year at the elementary schools in Anglophone Cameroon to six years to match with the Francophone subsystem (Fru \& Wassermann 2020). In 1974 the teaching of French in schools in the Anglophone region was made compulsory but this did not receive the same weight in schools in the Francophone zone. Right hand driving in the Anglophone region was substituted with the left hand being introduced from the francophone zone (Gwanfogbe 2018). In the face of these challenges, Anglophones have a sense of frustration and disillusionment. Even the recent creation of the National Commission on Bilingualism and Multiculturalism (NCBM) (Decree No: $2017 / 013$ of the $23^{\text {rd }}$ January 2017) as a palliative has not solved the problem, say so many Anglophones (Che 2019). It is a good initiative, but coming too late; it is merely cosmetic. 
There is widespread tendency amongst some Anglophones to put all their predicaments on the doorstep of the Francophone elite, and even the Francophone population. However, it is undeniable that the Anglophone political elite bears some share of responsibility for the Anglophone conflict. One would have expected them to resist the erosion of federal structures in 1972 , but this was not the case. Some of them campaigned vigorously for the supplanting of the federal structure. ${ }^{22}$ When they realised that their influence within the federal state of West Cameroon had begun to weaken and that the federal arrangements no longer suited their designs, they started competing first for Ahidjo's and later Biya's favours, aspiring for power positions, first within the single party and federal governments, and eventually within the unitary state, and thus neglected blatantly the defence of West Cameroon's autonomy and interests (Kofele-Kale 1987).

Perhaps the cooptation of the Anglophone political elite into the 'hegemonic alliance' (Bayart 1979) by Ahidjo explains partially why Anglophones could not raise their voices. But when Biya assumed power in 1982 and 'opened the gates of freedom' through his New Deal policy programme, Anglophones were expectant and hopeful that he would address their preoccupations. They were impressed that he addressed all Cameroonians from Bamenda and Buea in English, something which his predecessor did not do in his 22-year reign. The Anglophones felt that their complaints would be listened to, but to their chagrin, the 'Anglophone Problem' has aggravated to unprecedented levels since 1990, reaching a climax in 2016 and turning into a violent war in 2017.

\section{Conclusion}

Following the models of Fanon ( 1972) and Mamdani (1996) the Cameroon state today is a reflection of the colonial state. From 1961, the state of Cameroon was more a Gallic state than an Anglo-Saxon state. The British tried to tie British Southern Cameroons to Nigeria but the political elite who were more or less educated in Nigeria were enlightened enough to reject a Nigerian connection. At the end of the day the British and the UN were held responsible for incomplete decolonization. However, they cannot be blamed completely for the war which is going on in Cameroon. This paper has taken Decoloni-

${ }^{22}$ File Vc/ 1972/1, Confidential campaigns for the Referendum, Re (NAB) 
sation in the political realm which has come to mean the period in which African colonies were shaking off colonial powers from African territories. Anglophone Cameroon, which is the erstwhile British Southern Cameroon, has been involved in a war with French Cameroon since 2017. This war which has been dubbed Ambazonian War of independence has its roots traced to the partition of German Cameroon in 1916, and the reunification of British Cameroons with French Cameroon in 1961. The way in which the British administered the territory and the complicity of the UN failed to give the British Cameroons a third option which would have granted them independence as an autonomous polity. Hence, this paper has attempted to focus on the ongoing crisis in Cameroon by saddling this crisis onto the shoulders of decolonisation and the Cameroon postcolonial state. This is a shift from the way it has been handled in the literature by blaming the Francophoneled government, being responsible for the Anglophone war. From the foregoing discussions amongst other things, three trajectories emerge. First, the politicians of the late 1950s had their share of blame. Cameroon politicians played a key role in the decolonization of the territory. Most of these politicians agreed to disagree on the political future of the territory. The UN did not make matters better. It would have placed the Plebiscite questions above party politics but unfortunately it appears that it had no other better choice than to do so. Outstanding politicians like Ahmadou Babatoura Ahidjo, John Ngu Foncha, and to a lesser extent Emmanuel Lifafa Endeley played significant roles in the decolonization process of French and British Cameroons, the reunification process, and its immediate aftermath. In most of the literature, they are presented as responsible for the negotiations with the United Nations and with the colonial powers - Britain and France. They have also been presented as leading the reunification campaign in the British zone, and for facilitating the post-plebiscite discussions that culminated in the formal proclamation of reunification (Fru \& Wasseman 2020:68). The insinuation here is that without these 'great' Anglophone men, reunification would not have happened. And without reunification the war today would have been largely averted so to say. Secondly, Britain and the UN also played their own role. Britain did not play her role as much as she was expected to as a UN trusteeship power. By administering the British Southern Cameroons as part of the Eastern Provinces of Nigeria rather than just a UN Trusteeship, the outcome was to a large extent the inevitability of war which is going on today. The UN, combined with Britain, seems to have conspired to deny the Southern 


\section{Walter Gam Nkwi}

Cameroonians the option which would have been for Southern Cameroons gaining independence as a separate autonomous state. The various financial commissions which the British put into place between 1954 and 1959 were set up to report the obvious. The conclusions were therefore used to deny British Southern Cameroons the option of independence as an autonomous state. Thirdly, the post independent political elite need to carry their own share of the blame for failing to manage a nation-state coming from two different cultural backgrounds - French and English. An examination of the claims of most Cameroonians suggest that since the union of British Cameroons with French Cameroons most if not all things including currency, left hand driving, and French language, just to name a few left French Cameroon into Anglophone Cameroon. Seemingly, none left British Southern Cameroons to French Cameroon. By hindsight, this caught the attention of one of the Anglophone intellectuals, Bernard Fonlon as early as 1964 when he captured the title of his book, Will we make or Mar. To borrow a leaf from Fonlon and buttress some of the conclusions, he said inter alia;

... but in this federation, West Cameroon occupies a position that is inferior geographically, inferior demographically, inferior politically, inferior in resources. The numerical, territorial, and economic inferiority of Southern Cameroons is a self-evident fact, but the political side of it may need an explanation. This federation came into being with the union of two states, one (the Cameroon Republic) already endowed with external sovereignty and the other (Southern Cameroons) scarcely enjoying internal self-government. There could be, therefore, no bargaining between them as between equal; for, at the conference table, Southern Cameroons could not speak with that dignity, that authority, that is the prerogative, today, of even tiny Zanzibar. The result of this many-sided inequality is that, in this federation, that initiative of which I spoke above, that power to introduce policy, to shape the course of events in things political, economic, social and cultural, lies, to all intents and purposes, entirely in the hands of East Cameroonians (Fonlon 1964:56).

By this very fact, the post-colonial state has remained for most of the time a reflection of a colonial state. In this post-colonial state some citizens feel that they have not been included into the circles of the nation state project. This has 
been the feeling of most Anglophones. Yet the very inferiority position through which British Cameroons entered the union is surely a point to the foundation of the present Ambazonian War. Above all, as I have argued in the article, the Anglophones ought to realise that by virtue of the share size in comparison with French Cameroon as well as their size and population disparity, they can never be equal to the French Cameron. Within this dilemma, this paper proposes that the Francophone led dominated government should put viable and vibrant federal structures to make the citizens of Cameroon be included and feel a sense of belonging.

\section{References}

Akiba, O. 2021. Political Change and Constitutionalism in Africa. London: Routledge.

Amazee, V.B. 1990. The 'Igbo Scare' in the British Cameroons, c. 1945 - 1961. The Journal of African History 31: 281 - 293.

Ardener, E. 1967. The Nature of the Reunification of Cameroon. In

Hazlewood, A. (ed.): African Integration and Disintegration: Case

Studies in Economic and Political Union. London: OUP.

Ardener, E. \& W.A. Warmington 1960. Plantation and Village in the

Cameroons: Some Economic and Social Studies. Oxford: OUP.

Austen, R.A. 1974. The National Archives of Cameroon. History in Africa 1: $153-155$.

Awasom, N.F. 2003 - 2004. Anglo-Saxonism and Gallicism in Nation Building in Africa: The Case of Bilingual Cameroon and the Senegambia Confederation in Historical and Contemporary Perspective. Afrika Zamani 11 \& 12: 86 - 116.

Awasom, N.F. 2020. The Anglophone Problem in Cameroon Yesterday and

Today in Search of a Definition. Journal of the African Literature Association 14, 2: 264 - 291.

Awasum, N. 1998. Colonial Background to the Development of Autonomous

Tendencies in Anglophone Cameroon, 1916 - 1961. Journal of Third World Studies xv, 1: 168 - 183.

Bayart, J.F. 1993. The State in Africa: The Politics of the Belly. London: Longman.

Bayart, J.F. 1978. The Neutralisation of Anglophone Cameroon. In Gaullist Africa: Cameroon Under Ahmadu Ahidjo. Ibadan, Nigeria: Fourth 
Dimension Publishers.

Che, C. 2019. An Analysis of of Decentralisation under the 1996 Constitution of Cameroon. PhD Dissertation, University of Pretoria.

Chem Langhee, B. 1995. Anglophone - Francophone Divide and Political Disintegration in Cameroon: A Psycho-historical Perspective. In Nkwi, P.N. \& F.B. Nyamnjoh 9eds.): Regional Balance and National Integration in Cameroon: Lessons Learned and the Uncertain Future. Yaounde: ASC/ ICASSR.

Chiabi, E. 1989. British Administration and Nationalism in Southern Cameroons, 1954 - 1964. In Njeuma, M.Z. (ed.): Introduction to the History of Cameroon Nineteenth and Twentieth Centuries. London: Macmillan.

Christopher, A.J. 2003. Decolonisation without Independence. GeoJournal, 56: $213-224$.

Churchill, W. 2010. Triumph and Tragedy: The Second World War. Volume 6. London: Rosetta Books.

Crowder, M. 1984. The Second World War: Prelude to Decolonization in Africa. In Crowder, M. (ed.): The Cambridge History of Africa. Volume 8. from c. 1940 -c. 1975. Cambridge: Cambridge University Press.

Dudley, B.J. 1984. Decolonisation and the Problems of Independence. In Crowder, M. (ed.): The Cambridge History of Africa. Volume 8. from c. 1940 -c. 1975. Cambridge: Cambridge University Press.

Ebune, J. B. 1992. The Growth of Political Parties in Southern Cameroons, 1916 - 1960. Yaounde: CEPER.

Elango,L.Z. 1985. The Anglo-French 'Condominium' in Cameroon, 19141916: The Myth and the Reality. The International Journal of African Historical Studies 18, 4: 656 - 673.

Englebert, P. \& R. Hummel 2005. Let's Stick Together: Understanding Africa's Secessionist Deficit. Journal of Contemporary African Studies 16,2: 249 - 276.

Ezra, A. 1967. Constitutional Developments in Nigeria: An Analytical Study of

Nigeria's Constitution-Making Developments and the Historical and Political Factors that Affected Constitutional Change. London: Cambridge University Press.

Fanso, V. G. 1999. Anglophone and Francophone Nationalisms in Cameroon. Round Table 350, April.

Fanso, V.G. 1985. African Traditional and European Colonial Boundaries: 
Concepts and Functions in Inter-Group Relations with Special Reference to South Western Cameroon. Journal of Historical Society of Nigeria 12, $3 \& 4: 23-43$.

Fanso, V.G. 1989. Cameroon History for Secondary Schools and Colleges. Volume II: Colonial and Post-Colonial Times. London: Macmillan.

Forest, J.B. 2004. Subnationalism in Africa: Ethnicity, Alliances and Politics Boulder/ London: Lynne Rienner.

Fonlon, B. 1964. Will we Make or Mar? Buea, Cameroon: Government Printers.

Fru, R.F. \& J. Wassermann 2020. Constructions of Identity in Cameroonian History Textbooks in Relation to the Reunification of Cameroon. Journal of Educational Media Memory and Society 12,2: 57 - 76.

Gardinier, D.E. 1963.Cameroon: United Nations Challenge to French Policy. Oxford: Oxford University Press.

Gwanfogbe, M.B. 2018. Changing Regimes and Educational Development in Cameroon. Denver: Spear Media.

Jansen, J.C. \& J. Osterhammel 2017. Decolonisation: A Short History. Princeton, NJ: Princeton University Press.

Johnson, W.R. 1970. The Cameroon Federation: Political Integration in a Fragmentary Society. Princeton: Princeton University Press.

Joseph, R. (ed.). 1978. Gaullist Africa: Cameroon under Ahmadu Ahidjo. Enugu: Fourth Dimension.

Jua, N. \& K. Piet 2004. Occupation of Public Space: Anglophone Nationalism in Cameroon. Cahiers d'études africaines 175: 1 - 18.

Kale, P.M. 1967. Political Evolution in the Cameroons. Buea: Government Printer.

Kofele-Kale, N. 1987. Class, Status, and Power in Post-unification Cameroon: The Rise of an Anglophone Bourgeoisie, 1961- 1980. In Markovitz, I.L. (4ed.): Studies in Power and Class in Africa. New York: Oxford University Press.

Konings, P. 1993. Labour Resistance in Cameroon. Managerial Strategies \& Labour Resistance in the Agro-Industrial Plantations of the Cameroon Development Corporation. London: James Currey.

Mamdani, M. 1996. Citizen and Subject: Contemporary Africa and the Legacy of Late Colonialism. London: James Currey.

Mbile, N.N. 2000. Cameroon Political Story: Memories of an Authentic Eye Witness. Limbe: Presbook. 
Mbuagbaw, T.E., R. Brian \& R. Palmer 1987. A History of the Cameroon. New Edition. Essex: Longman.

Milne, M. 1999. No Telephone to Heaven: From Apex to Nadir - Colonial Service in Nigeria, Aden, the Cameroons and the Gold Coast. Hants: Meon Hill.

Ndongko, W.A. 1975. Planning for Economic Development in a Federal State:

The Case of Cameroon, 1960 - 1971. Munich, Germany: Weltforum Verlag.

Ngoh, J.V. 2001. Southern Cameroons, 1922-1961: A Constitutional History. Aldershot and Burlington: Ashgate.

Ngoh, V.J. 1996. History of Cameroon since 1800. Limbe: Presbook.

Ngoh, V.J. 1999. The Origin of the Marginalisation of Former Southern Cameroonians (Anglophones), 1961- 1966: An Historical Analysis. Journal of Third World Studies 160: 165 - 183.

Ngoh, V.J. 2020. Cameroon 1884 - Present: The History of a People. Limbe, Cameroon: Design House.

Njeuma, M.Z. (ed.). 1989. Introduction to the History of Cameroon in the Nineteenth and Twentieth Centuries. London: Macmillan.

Njung, G.N. 2019. The British Cameroons Mandate Regime: The Roots of the Twenty-First-Century Political Crisis in Cameroon. The American Historical Review 124, 5: 1715 - 1722.

Nkwi, W.G. 2013. Colonial Hegemonies at Loggerheads: British 'DeGermanisation' Policy in British Cameroons, 1916 - c. 1961. In Apoh, W. \& B. Lundt (ed.): Germany and Its West African Colonies: Excavations of German Colonialism in Post-Colonial Times. Frankfurt: Lit Verlag.

Nyamnjoh, F.B. \& P. Konings 2004. President Paul Biya and the 'Anglophone Problem' in Cameroon. In Mbaku, J.M. \& J. Takougang (ed.): The Leadership Challenge in Africa: Cameroon under Paul Biya. Trenton: Africa World.

Orosz, K.J. 1996. Colonial Archives in Cameroon. Africa Research and Documentation: Journal of the Standing Conference on Library Material on Africa 71: 33 - 40.

Pearce, R.D. 1982. The Turning Point in Africa: British Colonial Policy 1938 - 1948. London: Oxford University Press.

Percival, J. 2008. The 1961 Cameroon Plebiscite: Choice or Betrayal. Mankon, Bamenda: RPCIG.

Rubin, N. 1971. Cameroon: An African Federation. London: Pall Mall. 
Smith, A.W.M. \& C. Jeppesen 2017. Introduction: Development, Contingency and Entanglement: Decolonization in the Conditional. In Smith, A.W.M. and C. Jeppesen (eds.): Britain, France and the Decolonization of Africa: Future Imperfect?. California: University of California Press.

Walter Gam Nkwi Assistant Professor Universiteit Leiden Leiden, The Netherlands Nkwi.walters@gmail.com. 